\title{
Water Springs as a Resource for Nature Tourism in Latvia: a Tourist Perspective
}

\author{
Janis Bikse, Ph D Scholar \\ Vidzeme University of Applied Sciences \\ Cesu Street 4, Valmiera LV-4200 LATVIA \\ janis.bikse@va.lv; http://va.lv
}

\author{
Mahender Reddy Gavinolla, Assistant Professor, \\ National Institute of Tourism \& Hospitality Management \\ Gachibowli, Hyderabad, INDIA -500032; www.nithm.ac.in \\ Guest Lecturer, Vidzeme University of Applied Sciences, \\ LATVIA mhender.reddy@va.
}

\begin{abstract}
Water springs are considered as one of the important natural resource for tourism due to its socioeconomic, cultural, health and religious benefits. Tourists are motivated to visit the water springs due to various reasons like sacredness, health benefits, education and cultural enrichment. Latvia is blessed with several water springs, which are potential attractions for the sacred water or holy water tourism. There are several studies conducted on various aspects of water springs in general. However, the research in the context of tourism, particularly motivations and interest of tourist is very scant. In this regard, aim of the paper is to know the motivations and potential benefits of the water spring tourism to tourist in Latvia. Initially authors reviewed existing literature to know the state of the spring tourism. Semi structured interviews and online-survey method to obtain visitors responses. Interviews were held with the visitor, covering various aspects like motivations and benefits of water spring tourism. To the best of the author's knowledge, very few studies conducted on spring tourism in Latvia, to provide a detailed overview on tourist motivations and potential benefits of visiting water spring tourism. Overall, the study results provide the basis for understanding the most frequently visited water spring resources by the tourists in Latvia. Nature appreciation, natural setting followed by mineral and health benefits are the major reasons to visit the water springs. Further, it allows decision makers to incorporate tourist opinion and their suggestions in the sustainable planning, promotion and management of water springs as tourist destinations in Latvia.
\end{abstract}

Keywords - Water Spring Tourism, Sacred Water, Tourist Motivation, Latvia

\section{INTRODUCTION}

Visiting the natural spring water for bathing and medical purpose to feel good and spiritual and physical health is in practice for the ages [1]. For example, archaeological evidence shows that several Asians used water springs for about 3000 years before Christ and Japanese used 11000 years ago [2]. Several studies mentioned the sacredness and spiritual importance of the spring water [3]. In India, it is quite common that people take bathing in hot water springs with the belief and faith that it would lead to longevity and curing several diseases like arthritis and skin diseases [4]. Owing to the potential benefits of the springs, several rulers gave immense importance to build tanks, gardens and creation of beautiful landscape for the visitors in the vicinity of the water springs [1]. The creation of pilgrimage centres and building temples around the springs shows evidence of strong belief [5]. Irrespective of the religion or religious beliefs people often visit holy springs with a belief that their wishes will come true on certain occasions and will also supernatural powers [6], fertility power [7], [8]. For example, several people visit the Orthodox Greeks Church in Büyükada, İstanbul annually on the 23rd and 24th day of April month. Further, they believe that the spring water is curative so that drinking and sprinkling on the face or hand will cure some diseases [9].

As per the UNESCO and IUCN, due to the sacred nature and spiritual significance, springs can be considered under the sacred natural sites [10]. This has further led to the recognition of springs as sacred natural sites as protected areas in various places [11]. Water springs are considered as one of the important natural resources for tourism due to their socio-economic, cultural, health and religious benefits [12], [13]. Sacred water springs are significant tourist attractions in several countries that provide several recreational and socio-cultural and economic benefits [14], [15]. Due to its nature, location and multiple characteristics, the water springs are considered as a resource for nature tourism, cultural tourism, religious 
and spiritual tourism and wellness tourism. It is widely understood that the tourist motivation is multi-faceted consist of several reasons and interest to visit the destination [16]. Similarly in the context of sacred water springs, there are several motivations to visit the sacred springs. For example, mystical power [17], to perform the rituals [18], touching and drinking the water for the transformation of life and rebirth [19], [5], [20], spiritual motives [1], curing diseases and healing power [4], [21], appreciation of the culture and nature [22]. Latvia is one of the popular destinations for the several water springs used as a resource for the spiritual, health and wellness, therapeutic and recreational purpose considering the geothermal, mineral and sacred benefits. Nonetheless, the scientific production of literature to understand the usage of spring as a tourism resource is scarce.

There are few studies conducted on various aspects of water springs as a resource for the tourism and motivational factor of the tourists in general? However, the research in the context of tourism, particularly motivations and interest of tourist is very scant. In this regard, the aim of the paper is to know the usage of springs as a resource for tourism, and the motivations and potential benefits of water spring tourism to the tourist in Latvia. In doing so, the authors tried to understand the concept of sacred spring tourism and the usage of sacred springs as a resource of tourism in general. More precisely, to know how the sacred water springs used a resource for tourism in Latvia, and further, the study tried to investigate motivations and benefits of visiting sacred water spring in Latvia. The structure of the chapter includes the theoretical background on water spring tourism and tourist motivations. Then the study elucidates on the methodological framework followed by the contextual framework. The latter part deals with the findings, discussions and conclusion, limitation and future scope of the study.

\section{Review of the literature}

Over the centuries, spring water is considered an important element on Earth that has several benefits [23]. Most importantly spring water is considered sacred in nature due to the spiritual, therapeutic and mineral benefits. It is also believed that it gives magical power and cures several diseases. [24]. It is important to know the tourist motivations for the market segmentation of spring tourism products and also to the sustainable management of the destinations. [16]. People may visit them because of the sacred power that they obtain by touching the water, with the hope that it would lead to a life transformation or an important and better pathway [20].

Water springs are also associated with legends and religious activities. Due to this, there are several religious buildings established in the vicinity of the sacred water spring sites. This is further giving an opportunity for recreation tourism for several tourists [25]. For example, springs in Western Kazakhstan surrounded by beautiful landscape, nature and also associated with spiritual and healing power. These are promoted as tourist products [26]. Springs are also considered life-giving sacred powers. For instance, springs dedicated to Virgin Mary at Acropolis in Greece shows a similar belief [27].

It is also observed in the previous studies that men and women exhibit different interests and interact differently with sacred water resources [28]. With increased interest to visit springs by the Europeans in the 18th and 19th century, several of them were converted to a commercial resource of recreational, medical and health tourism attractions [29]. Despite several benefits, overexploitation, irresponsibly managed destinations with mass tourism are sources for several negative impacts, leading to pollution and change in the water quality in several sacred water spring destinations [4], [27].

Water springs are generally divided into two basic types. Gravity springs (descending springs, hillslope springs) - emerge under unconfined conditions where the water table intersects the land surface. The water moves through the ground until it reaches a layer it can't penetrate and starts flowing horizontally until it reaches an opening and water comes out as a spring. Gravity springs are usually found along hillsides or on sandy or gravel slopes. Gravity springs commonly form a spring run without a pool. Artesian springs (rising springs, ascending springs) - discharge under pressure due to confined conditions in the underlying aquifer. The pressure inside the confined aquifer (due to being confined between impermeable formations) is higher than the pressure outside the aquifer, so the water moves in that direction, preferably to converging to joints or faults perforating the upper confined layer. Artesian springs often discharge into a pool, in the bottom of which spring boils occur. By conducting structured interviews, including nature tourism guides, authors obtained answers about the interests of tourists. If we look at the springs from this point of view, then the artesian springs where the water "boils" attract more interest.

\section{MATERIALS AND METHODS}

The study is conducted by using a mixed methodology. In the first phase, the authors reviewed published literature to understand the state of spring tourism and the usage of water spring as a resource for the various forms of tourism. In the second phase, the authors further used a survey method such as an online survey. It was a random study sampling. Total respondents were $126(n=126)$ in which 51 respondents are male and 75 are female visitors with an average age of 40 years. In the third phase, 10 semistructured interviews were conducted with the visitors at the site, to obtain the primary data on various aspects like motivations and benefits of water spring tourism. To better understand the sacred spring water as a resource of tourism in Latvia, authors tried to explore the various motivational factors, frequency of the visit, the season 
most frequently visited springs. For which, semistructured interviews were conducted. Detailed findings are provided in the result section followed by discussion.

\section{History and Profile of water springs in Latvia}

Water springs are popularly known for the use of springs for health and medical use, due to this spring water-based health tourism is well-known in the Baltic States. Several traditional thermal baths and rehabilitation resorts located across the Baltic seaside, these include Jurmala and Liepaja in Latvia. There are several thermal spas and seaside resorts established over a century ago. Considering the potential spring resources, Baltic Health Tourism Cluster was created in the year 2013 for better collaboration among the states and to improve the quality of the services and marketing of the destinations [30]. However, the literature shows that there are several other reasons to visit water springs in various parts of the world. Considering this, and with the evidence of the lack of literature in the Baltic context, this study is mainly focused on Latvian water springs as a source for tourism.

Latvia is known for the diverse springs with great history. The documented history of water springs in Latvia is related to the springs flowing from the caves shows that the oldest the cave year 1521 mentioned in literature is from Gutmanis Cave [31], [32]. There is a spring in Gutmanis Cave can give away youth. Gutmanis Cave is not only the oldest but also the most visited tourist attraction (see Fig.1). XX century in the second half, it was visited by about 1.5 million tourists every year [33]. The cave is mentioned as the most visited by tourists in the Soviet Union [34], [35]. The number of visitors to the cave and spring as 1.5 million is also mentioned in 1989 [36].

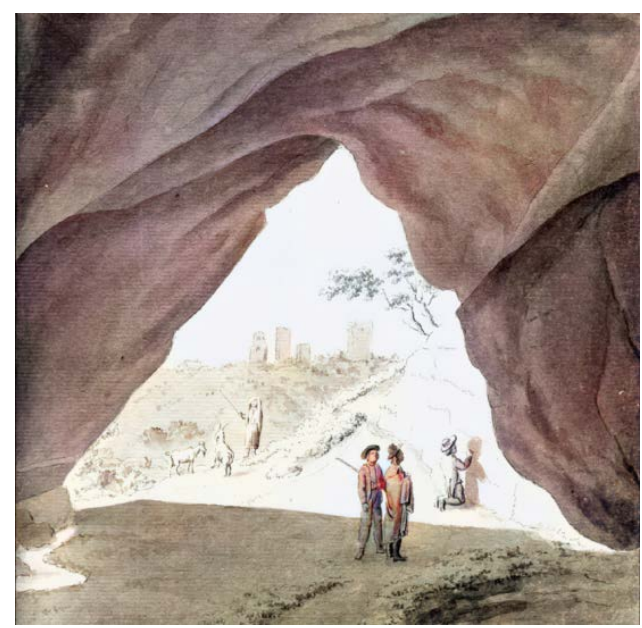

Figure.1 Gutmanis cave. Spring on the left. (Source: Brotze 1794)

In the Republic of Latvia, number of visitors to Gutmanis cave grows from 100 thousand in 1993 to almost 300 thousand in 2019 [37].

Liepa Lielā Ellīte (Devil's Oven) is an equally old, popular tourist attraction from water-rich springs (see
Fig.2). The descriptions tell of even older annual figures [38]. Lielā Ellīte, like Gutmanis cave, is located near the ancient road, so it must be thought that they were already known in the 12th century [39].

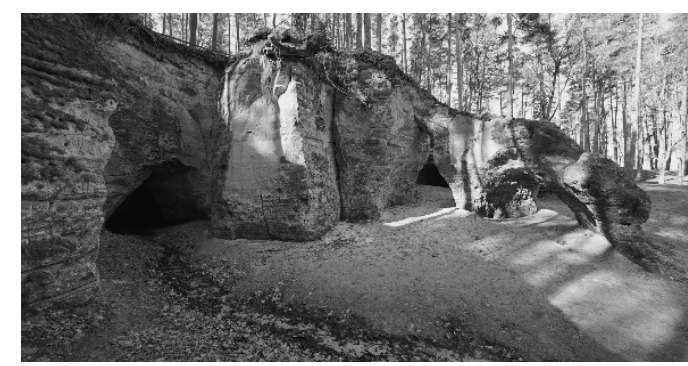

Figure.2 Liepas Lielā Ellīte (Devil's Oven).

Liepas Lielā Ellīte is the third most popular spring in Latvia. Also one of the earliest known. With cave and three natural arches.

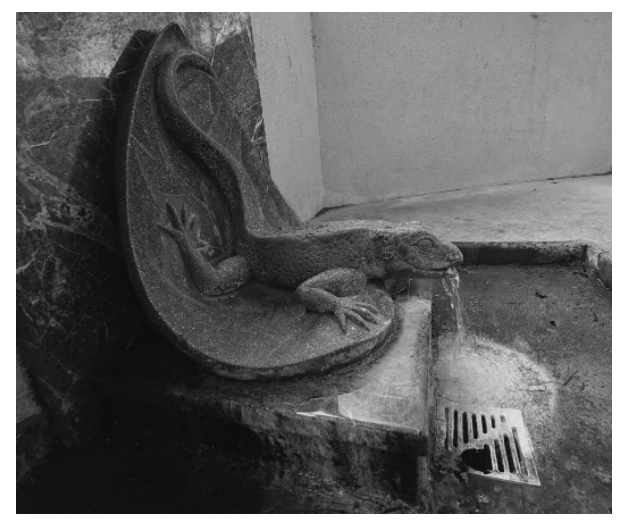

Figure.3 Baldone sulphur spring "lizard".

Baldone was a famous sulphur water resort in the past (see Fig.3).

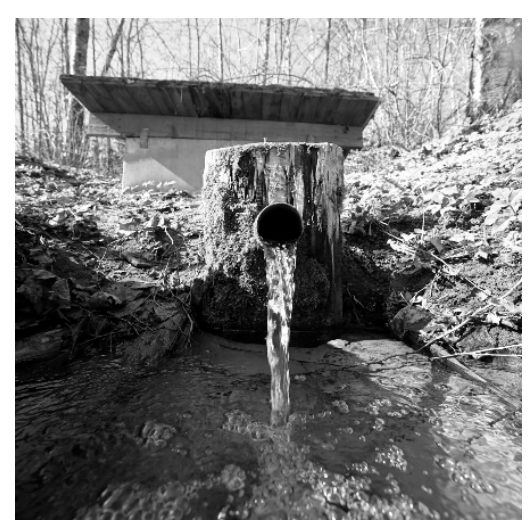

Figure.4 Gaujiena Spring of the right bank of the river Gauja.

Gaujiena Spring is a popular water intake (see Fig.4).

Currently, Lielbāta spring water is also sold in PET bottles (see Fig.5). 


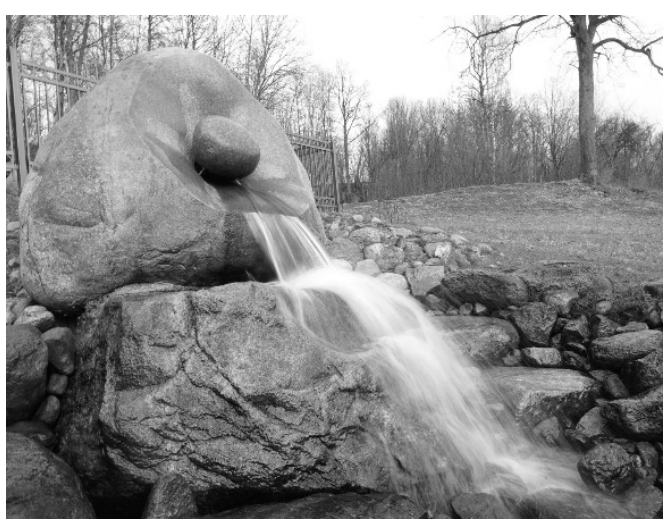

Figure.5 Lielbāta water spring.

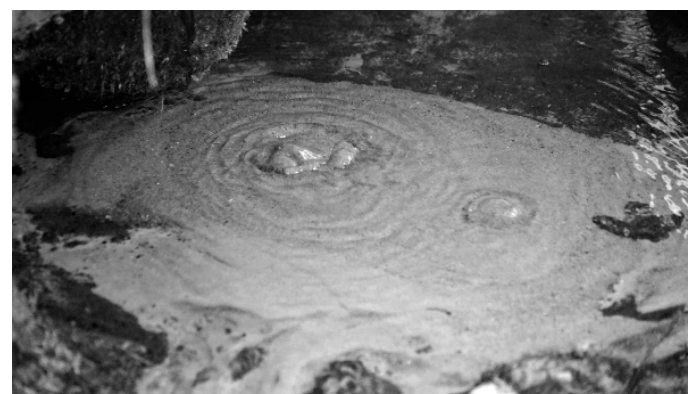

Figure.6 The sacred spring of the Boleni.

Boleni Spring helps against eye diseases (see Fig.6). One of the artesian (fountain) springs, which is very popular with tourists.

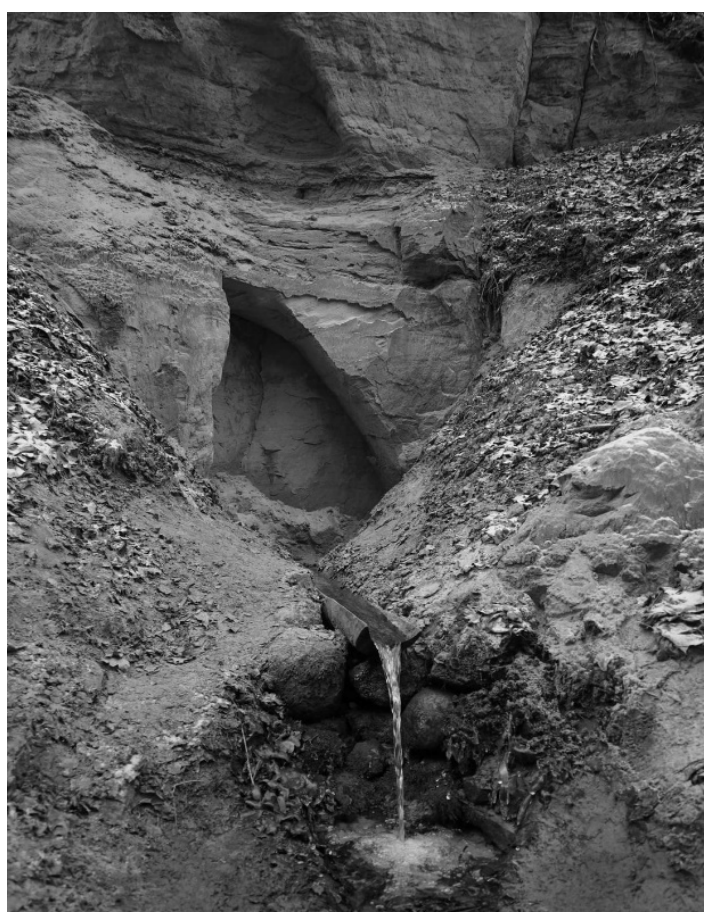

Figure.7 Satezele spring.

The Satezele spring is located next to an ancient Liv castle. Currently, it is visited both as a beautiful natural object, where the spring flows from a sandstone cliff (see Fig.7). It is also visited by people who want to get qualitative drinking water.

\section{RESULTS AND DISCUSSION}

To understand the frequency of the visit to the spring in a year, we asked the respondents how many times they visited springs in Latvia last year. Results show that only $15 \%$ of the respondents visited for the first time and the majority of the respondents (56\%) visited a minimum of 1 time to a maximum of 5 times (see Fig. 8). Interestingly about $29 \%$ of them visited minimum of 5 times and more.

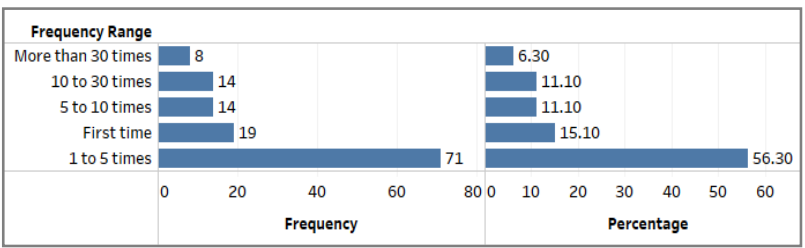

Figure 8. Frequency of the visit

Literature shows that there are several other motivations other than spiritual benefits. In this regard, the authors asked the questions on motivations to visit the springs to understand the motivational factors. Result revealed that there are multiple motivations to visit the springs. Most of the respondents (about 50\%) visited due to the natural beauty of the object followed by extraction of water (25\%) (see Fig. 9). There are about $10 \%$ of the people visit mainly because of a historical object is surrounded by legend. About 8\% includes special benefits like health, youthfulness and life expectancy followed by others such as education, research, geo coaching, refreshing, thirst-quenching water, landscape and geology, etc.

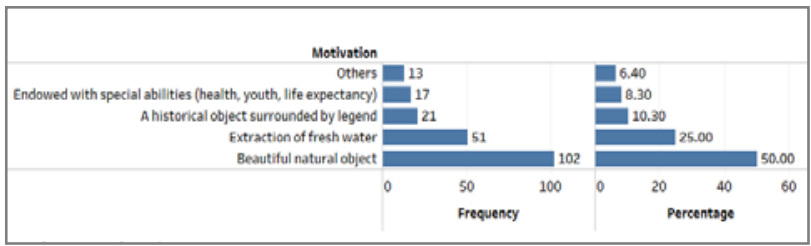

Figure 9. Motivations for the visit

Seasonality as one of the major factors that influences the visitors to visit the destination. Accordingly, the authors tried to understand the best season that the tourist visits the most (see Fig. 10). There are multiple answers by the tourist to visit the destination. However, majority (40\%) of them are visiting in the summer, $25 \%$ of them are visiting in spring followed by the fall and winter with $20 \%$ \& 15\% respectively.

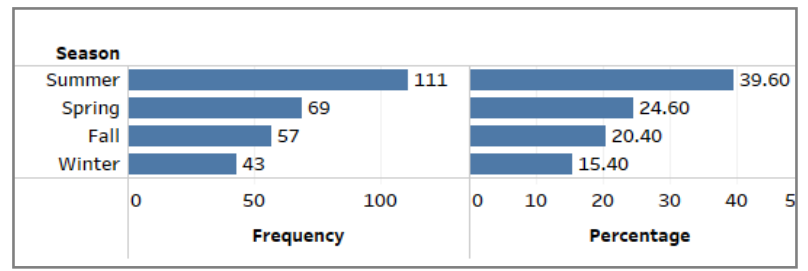

Figure 10. Season of the visit 
Further authors tried to understand the most frequently visited spring destination in Latvia. However, we have important to know the most frequently visited springs (see Fig. 11). Results show that "Gutmanalas avots" and "Raunas Staburags' are the most popular springs visited by almost $15 \%$ each followed by "Lielās Ellītes avots" with $10 \%$. Next popular springs include "Mazās Ellītes avots”, “Aglonas svētavots", "Velna Skābumaḳērne Skaņkalnē" and "Ķemeru ķirzaciņa".

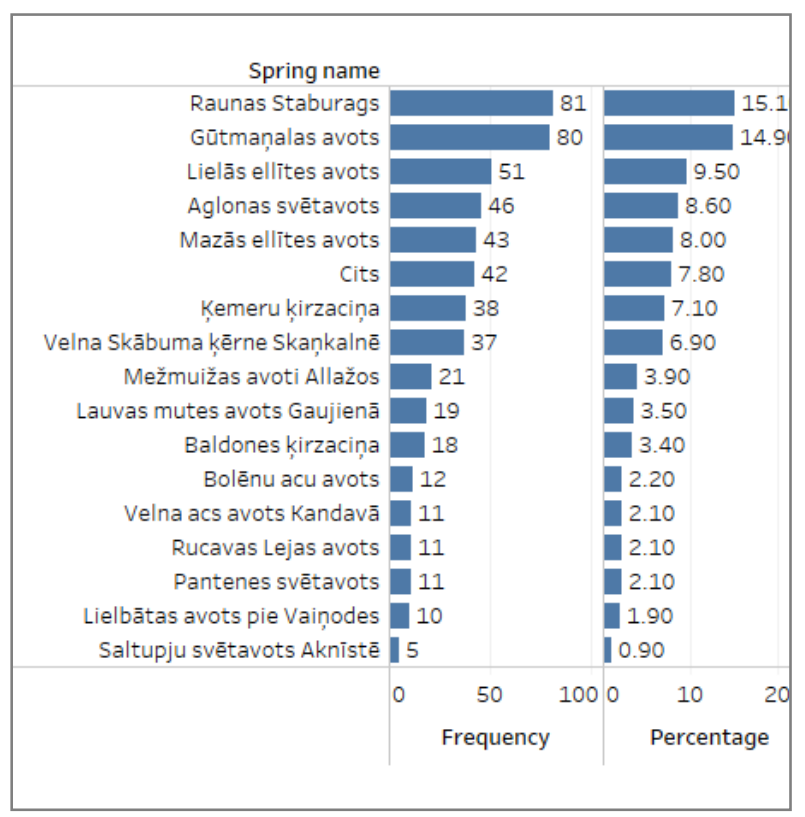

Figure 11. Most frequently visited spring

A very important section of the survey is about the motivations for a tourist visit. It shows that in $50 \%$ of cases, tourists visit water sources as beautiful and interesting natural objects. Springs are often associated with objects created by the influence of springs as caves, grottoes, travertine cliffs. Such tourist objects are related to the most frequently visited Latvian springs - Raunas Staburags (travertine cliff), Gutmanala (grotto, cave), Liepas Lielā Ellīte (cave and three natural arches). The second most common reason for visiting springs is to get drinking water. The third reason is history - there are legends about many springs. As in other countries, many of the water sources have been known for many centuries and have a sacred significance. Some springs have special abilities - to regain youth, improve eye light, and improve health. People have also mentioned that they have visited the springs as a geocaching point, how to learn geology and nature, how to perform sacred rituals, how to refresh, how to walk with or without children. The answers also show seasonality in the visit to the springs. In summer it is higher, then spring, autumn and winter. The good news is that people visit the springs in all seasons.

The authors also conducted semi-structured interviews with people at springs. The authors interviewed the people who took water from Rūcamavots spring near
Cēsis, Oliṇu spring near Seda, Zāǵezers spring near Valka, Vecsautini spring near Smiltene. The main reason for taking water is qualitative water with good mineral composition. It replaces the water supplied by the city's water supply. In the water supply, the water tends to be tasteless, with colour and bad smell in some places. Water is filtered, coagulated, sorbents are used, disinfected (chlorinated, ozonated, irradiated with ultraviolet light). Sometimes the water is further treated - Water softening, Fluorination, Iron removal, demanganization). All this reduces the belief in the water supply as a natural product. Most of the interviewed people were from the nearest urban areas as Cesis, Smiltene, Seda, Valka in the NorthEast part of Latvia called the Vidzeme region. They plan trips to the spring water in their free time. Sometimes they also supply water to neighbours. People whose work involves trips outside the city include one of the famous springs on the route to supply the family with valuable water.

Respondents consider such water from a spring to be more valuable as a spring of water from PET bottles. Some water traders also use a well-known spring of bottled water (Lielbāta spring, Cēsis Svētavots). Also in these cases, people prefer to choose "living" water from the spring. A detailed map of the springs is shown in the map (see Fig. 12).

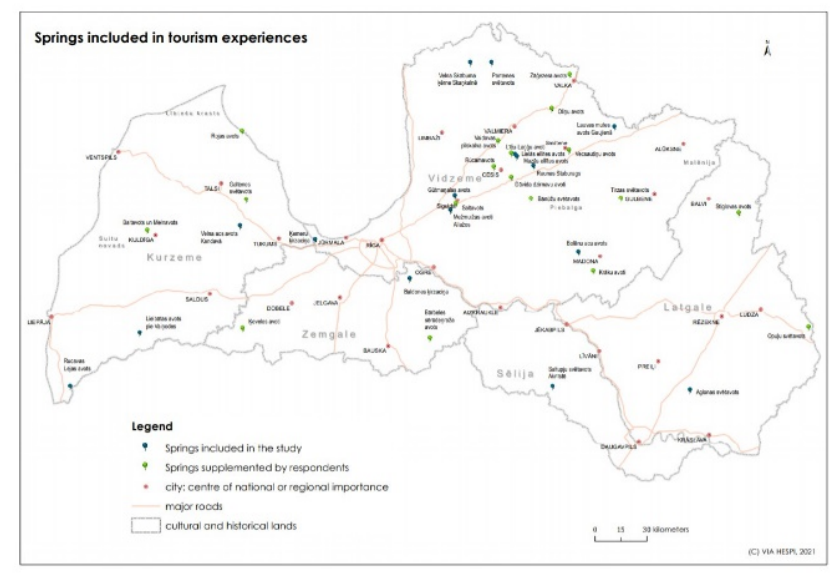

Figure 12. Springs included in the tourism experiences

Nature tourism is one of the important forms of tourism that provides several benefits to the visitors and local community [40], [41]. Spring can be considered an important tourism resource for Latvian tourism. It can be considered as an important nature-based tourism resource due to its natural characteristics and tourist interest to visit these places as a natural object. It is interesting that even in places where good natural water sources have not been preserved, they are created artificially, using the very rich selection of Latvia's underground mineral waters. Thus, in the development plan of Liepāja resort, one of the main accents is the use of groundwater. However, it is well argued in several studies that if tourism is overexploited 
and not managed properly, it will lead to several negative impacts such as overtourism, mass tourism, pollution and change in the natural settings [42], [43]. Keeping in view of this it is important to ensure that the spring resources managed and promoted in a sustainable manner to minimize the negative impacts and maximize the positive ones.

\section{CONCLUSION}

The study was aimed at understanding the sacred water as a source of tourism object in Latvia. In this regard, the authors reviewed the relevant literature on how the spring is used as a resource for tourism in general. Literature shows that there are different types of water spring based on the location and geographical features. Water springs are having a very long history and mostly used in the past for the purpose of spiritual, religious purpose followed by medical and health purpose. Due to its location and associated benefits, several countries promoting springs as a spiritual or sacred place, religious destination, health and wellness tourism activities. However, in the recent past, people started visiting for non-religious purpose and to enjoy nature, mineral benefits, and natural settings and water flow. Latvia is blessed with several springs and having several potential opportunities for the promotion of tourism. Considering the diverse and intensive springs it is important to promote them as a tourism attraction. In doing so, it is important to know the tourist interest and motivations to visit the springs. The authors conducted a survey on motivations, frequency, interesting and most frequently visited springs and seasonality. Result show that the Latvians are the frequent visitors to water springs. Results revealed that there are multiple motivations to visit the springs. But most of the visitors interested in seeing the natural beauty of the object followed by the extraction of water. Visitors are motivated by history and education. Based on these results, Latvian tourism authority may promote the spring water resources not only for the sacredness or spiritual purpose but also as a naturebased attraction due to the natural settings and geographical features. Seasonality is not a hindrance for the tourist as a visitor visiting all the seasons, however, the majority is visiting in the summer. "Gūtmannalas avots" and 'Raunas Staburags' are the majority of the most popular spring followed by "Lielās Ellītes avots" followed by "Mazās Ellītes avots", "Aglonas svētavots", "Velna Skābumak̦ērne Skaṇkalnē" and "Kemeru kirzacina" that the tourist showed the most interest to visit. Further, there are several visitors interested in education and history; accordingly, there is a scope to promote educational tourism for the children to understand the spring ecosystem, services. Further, results explained the most frequently visited water springs, most frequently visited spring water resources may be promoted in a sustainable manner. As mentioned in the discussion, if tourism is not properly managed it may lead to several negative impacts and leading to pollution and change of the spring ecosystem. Considering this sustainable management of the spring waters is an important aspect.

There are several limitations to the study. The study is conducted in the COVID-19 pandemic times, due to this there was an only domestic tourist visiting the water spring in Latvia. The study focused only on motivations, frequency and important places. Future studies should focus on the various aspects of spring tourism including implications of spring tourism on the local community, the status of the spring tourism attractions for sustainable management. There should be a study on the motivational factors of the international tourists to promote these places for the international market. There is a scope to study amenities, facilities and promotion of water spring tourism in Latvia. As the majority of the visitors are motivated with religious aspects in general, it is necessary to carry out additional research in Latgale research (orthodox, Catholics etc.). In this research, the semi-structured interviews were done in the Vidzeme region and future research can cover all the areas. Future research may use the quantitative survey to measure motivations in detail for both domestic and international tourists.

Acknowledgment: Authors would like appreciate and acknowledge the assistance provided by Dr.geogr. Andris Klepers for preparing the map and Dr.oec. Agita Livina for valuble suggestions. The European Social fund project 8.2.2. "To Strengthen Academic Staff of Higher Education Institutions in the Areas of Strategic Specialisation” funded this research partly for G. Mahender Reddy.

\section{REFERENCES}

[1] B. Kiełczawa, "Short history of thermal healing bathing," in Geothermal Water Management, 2018, pp. 303-318.

[2] I. B. Fridleifsson, "Geothermal energy for the benefit of the people,” Renewable and Sustainable Energy Reviews, vol. 5, no. 3, pp. 299-312, 2001.

[3] L. Coltelli, "Leslie Marmon Silko's Sacred Water," in Studies in American Indian Literatures, 1996, pp. 21-29.

[4] R. Bhutiani, D. R. Khanna, D. B. Kulkarni, M. Ruhela, "Assessment of Ganga River ecosystem at Haridwar, Uttarakhand, India with reference to water quality indices," Applied Water Science, vol. 6, pp. 107-113, 2016.

[5] D. Chandrasekharam, "A prehistoric view of the thermal springs of India,” presented at World, Geothermal Congress, 1999, pp. 385-388.

[6] V. E Hart, "The Waters and Water Spirits," in Votian Folk Beliefs, vol. 4, no. 12, pp. 6-37, 1999.

[7] F. Türkmen, "Batı Anadolu’ da Doğumdan Ölüme Bazı İnanmalar Üzerine,” in Türk Dili ve Edebiyatı Araştırmaları Dergisi, 1991, pp. 2-7.

[8] E. Akman, “Türkve Dünya Kültüründeki Su Kültü Üzerine Düşünceler," in KastamonuEğitimDergisi, vol. 10, no. 1, pp. 1-10, 2002. 
[9] M. N. Önal, "DağKültü, Eren Kültüve Şenliklerinin Muğla'dakiYansımaları,” Bilig. 25, 2003.

[10] R. Wild, C. McLeod, "Sacred Natural Sites: Guidelines for Protected Area Managers," in International Union for Conservation of Nature, Gland, Switzerland, 2008.

[11] N. Dudley, Z. L. Higgins, S. Mansourian, “The links between protected areas, faiths, and sacred natural sites," Conservation Biology, vol. 23, no. 3, pp. 568-577, 2009.

[12] C. F. Lee, B. E. King, "Using the Delphi method to assess the potential of Taiwan's hot springs tourism sector," International Journal of Tourism Research, vol. 10, no. 4, pp. 341-352, 2008.

[13] C. F. Lee, B. E. King, “Assessing destination competitiveness: An application to the hot springs tourism sector,” Tourism and Hospitality Planning \& Development, vol. 3, no. 3, pp. 179-197, 2006.

[14] P. Erfurt-Cooper, "The importance of natural geothermal resources in tourism," In proceedings World Geothermal Congress, 2010, pp. 1-10.

[15] Y. Mansfeld, O. Winckler, "Can this be spring? Assessing the impact of the "Arab Spring" on the Arab tourism industry,” Tourism: An International Interdisciplinary Journal, vol. 63, no. 2, pp. 205-223, 2015.

[16] C. Ryan, "Motives, behaviours, body and mind,” In The tourist experience, 2002, pp. 27-57.

[17] J. Digance, "Pilgrimage at contested sites," Annals of Tourism Research, vol. 30, no. 1, pp. 143-159, 2003.

[18] M. Eliade, Myth and reality. London: Allen \& Unwin, 1964.

[19] J. Hannaford, J. Newton, "Sacrifice, grief and the sacred at the contemporary 'secular' pilgrimage to Gallipoli," Borderlands e-journal, vol. 7, no. 1, 2008.

[20] P. J. Margry, "Secular pilgrimage: a contradiction in terms?” In Shrines and pilgrimage in the modern world: New itineraries into the sacred, 2008, pp. 13-46.

[21] J. Dubisch, In a different place: Pilgrimage, gender, and politics at a greek island shrine, Princeton: Princeton University Press, 1995.

[22] N. Collins-Kreiner, "Research pilgrimage: Continuity and transformation," Annals of Tourism Research, vol. 37, no. 2, pp. 440-456, 2010.

[23] N. Altman, The Spiritual Source of Life Sacred Water, 2002.

[24] M. Eliade, "Sularvesusimgeleri," in DinlerTarihineGiriş. Çev. Lale Arslan, İstanbul, 2003.

[25] Y.A Absalyamova, “The Cult of Sacred Springs among the Bashkir,” Shaman, Budapest, vol. 27, pp. 45-53, 2019.

[26] K.M Akhmedenov, "Assessment of the Prospects of Springs in Western Kazakhstan for Use in Religious
Tourism,” Geojournal of Tourism and Geosites, vol. 31, no. 3, pp. 958-965, 2020.

[27] J. H Håland, "Water sources and the sacred in modern and ancient Greece and beyond," Water History, vol. 1, pp. 83-108, 2009.

[28] T. J. Baker, B. Cullen, L. Debevec, Y. Abebe, “A sociohydrological approach for incorporating gender into biophysical models and implications for water resources research,” Applied Geography, vol. 62, pp. 325-338, 2015.

[29] J. W. Lund, "Historical impact of geothermal resources on the people of North America," in Stories from a heated Earth, our geothermal heritage, Geothermal Resources Council, Davis, CA, pp. 451-478, 1999.

[30] S. Melanie, "Baltic Health Tourism: Uniqueness and Commonalities,” Scandinavian Journal of Hospitality and Tourism, vol. 15, no. 4, pp. 357-379, 2015. DOI: 10.1080/15022250.2015.1024819.

[31] E. Guntis, Alas Latvijā, Rīga: Zvaigzne ABC 76.lpp, 2004.

[32] G.Urtāns, Gūtmaņa ala senākais tūrisma objekts Latvijā. Eiropas kultūras mantojuma dienas 2008. Neparastais mantojums. Rīga: Valsts kultūras pieminekḷu aizsardzības inspekcija. 54.-55. Lpp.

[33] O.Āboltiņš, G.Eniņš, Gaujas senieleja. 1979. Rīga: Liesma.136.lpp.

[34] Siguldas alas Vaduguns 1973.09.20 (Balvi)

[35] Siguldas alas Za PobeduKommunizma 1973.09.27 (Ludza)

[36] Kuršs, V., Eniņš, G., Stinkule, A., Straume, J., \&Venska, V. G̣eolog̣iskie objekti Gaujas nacionālajā parkā. 1989. Rīga: Zinātne, 5.lpp.

[37] Klepers, A. 2021. Apmeklētāju plūsmas uzskaites un visaptveroša monitoringa sistēmas izveide īpaši aizsargājamās dabas teritorijās - Natura 2000 vietās Latvijā (Latvian). Vidzemes Augstskola.

[38] Heervagen_Ludvig Vella ceplis. Mājas viesis. 1864. 13.janv. (Nr.2) 15.-16.lpp.

[39] Laime Sandis, Svētā pazeme, Rīga: Zinātne, 474.lpp, 2009.

[40] A. Livina, M. Reddy, "Nature Park as a Resource for Nature Based Tourism," in Environment Technologies Resources, Proceedings of the International Scientific and Practical Conference, vol. 1, pp. 179-183, 2017.

[41] I. Berzina, A. Livina, "The Model on Estimating Economic Benefit of Nature-based Tourism Services of Territories of National Parks, Latvia,” in 4th International Conference on Educational Technologies, Corfu: Greece University, Corfu, pp. 100-105, 2009.

[42] V. Kaushal, S. Sharma, G. M. Reddy, “A structural analysis of destination brand equity in mountainous tourism destination in northern India," Tourism and Hospitality Research, vol. 19, no. 4, pp. 452-464, 2019. 
[43] M. R. Gavinolla, V. Kaushal, A. Livina, S.K Swain, H. Kumar, "Sustainable consumption and production of wildlife tourism in Indian tiger reserves: a critical analysis," Worldwide Hospitality and Tourism Themes, 2021,. https://doi.org/10.1108/WHATT-08-2020-0091
[44] Z. Dumpe "Latvijas avotu sabiedriskā monitoringa vadlīnijas" 2017. Latvijas Universitāte. Maǵistra darbs

[45] Liepājas pilsētas dome. "Liepājas kūrorta attīstības koncepcija 2015.-2020.gadam”.

[46] http://laiki.lv/latvijas-avotu-karte/ 